\title{
Information Finding Practices of Knowledge Workers in the Field of Business and Economics
}

\author{
Abdus Sattar Chaudhry \\ College of Social Sciences, Kuwait University, Kuwait City, Kuwait \\ Email: abdussattarch@gmail.com
}

Received 30 March 2016; accepted 17 July 2016; published 21 July 2016

Copyright (C) 2016 by author and OALib.

This work is licensed under the Creative Commons Attribution International License (CC BY). http://creativecommons.org/licenses/by/4.0/

(c) (†) Open Access

\begin{abstract}
It is important for knowledge workers in the business sector to have access to information on companies, countries, investment opportunities, and projects. Survey of information finding practices of professionals in Kuwaiti companies showed that use of web sites, internal reports, and consulting with colleagues were preferred approaches for finding work related information. Business professionals also frequently used organizational sites, reports from financial analysts, business information services, and social media in seeking information. They listed lack of adequate information in databases and non-availability of information related to local financial situation as barriers to effective information finding. They considered their information finding skills as reasonable but wanted to get more training in searching online databases and web-based sources. The study showed that business organizations ought to make arrangements that frequently used sources were accessible to their employees on regular basis. It is also desirable that training in information skills is arranged by for enhanced information literacy at work.
\end{abstract}

\section{Keywords}

Information Literacy, Information Behavior, Business Information, Knowledge Workers

Subject Areas: Library, Intelligence and Philology

\section{Introduction}

Familiarity with relevant information sources and ability to find and use information effectively can play an important role in enhancing the capability of knowledge workers. This capacity is also referred to in this paper as information literacy at work. It is critical for knowledge workers in any field to remain competitive. Among other things, they can take advantage of the vast array of information available in different sources in their re- 
spective areas of activities. Ashill and Jobber [1] and Varga-Atkins \& Ashcroft [2] have pointed out that nature of information in the field of business and economics is complex. Lehmann and Carolyn [3] and Thaivant [4] reported that studies of information finding in these fields were also scarce.

This paper examines the information finding practices of knowledge workers in the corporate sector in $\mathrm{Ku}-$ wait. Information finding refers to activities and approaches deployed to search for information. It also includes study of preferences for information sources and perceived barriers to effective information finding. The term knowledge worker in this paper has been used interchangeably with professionals and employees. These employees generally hold graduate degrees in their respective area of work. They perform such work that generates knowledge as a by-product of their work. In general, such employees perform managerial work or perform tasks that require specialized training and education.

\section{Literature Review}

Information seeking principles and practices discussed in the previous studies on information seeking in other fields are also applicable to business professionals. But, some additional considerations needed to be reviewed because of the complexities involved in the business field. Majid, Hayat, Patel, and Rashna [5]; Du [6]; and Quinn and Leligdon [7] highlighted the distinct nature of information needs of business students and professionals at different levels in the marketing sector. They reported that business professionals face different types of challenges requiring access to special information sources. Bennett [8]; Hitch [9]; and Du, Zhu, and Chen [10] developed holistic understanding about modeling marketing professionals' information behavior in the workplace. Gunn and Miree [11] discussed business information literacy teaching at different academic levels and Hesseldenz [12] discussed information literacy for business students, the future financial professionals.

Mackenzie [13] pointed out that there was a tendency to seek and accumulate information with emphasis on the formal information search process when seeking to solve a problem. They used information on financial statements, balance sheets, income statements, statement of cash flows, and industry trends. They also used nonfinancial information in assessing the financial health of a company for an investment opportunity. KingsfordSmith and Williams [14] discussed the role of information in investors' decisions and identified the principal sources of information used by investors. They also discussed the reasons for use of these sources. They reported a gap in the financial economics and information disclosure literature, which rarely address how investors seek information. They reported that multiple channels of information seeking were being used by investors and highlighted that social inter-communication appears to be very important in financial information seeking.

Jin and Bouthillier [15] conducted a study of information seeking behavior of competitive intelligence (CI) professionals in Canada. They reported that CI professionals used five categories of sources including local databases, folders on shared drive, paper files, and local repository, and CRM database. Local database solution was the most widely used strategy among them. It was usually a customized database developed locally by various tools, such as Lotus Notes, Microsoft Access, Excel, SharePoint, Oracle, etc. Often times, the local database had a web-based interface, but access to it was limited. Many participants used the local solution as a central repository to store, catalogue, and search information. Some participants stated that they did not use a formal database structure to store information and established folders on a shared drive internally.

Skyrius and Bujauskas [16] conducted a study about the awareness of information needs to gain insight into the user side in meeting complex information needs in business. Based on a survey of Lithuanian business managers, they confirmed the heterogeneous nature of complex information needs. They pointed out the most important groups of information being monitored were competition and market information, accounting and financial information, and customer information. They found that it was possible to perform a basket analysis of the types of information used and discover patterns of information groups. They suggested that these patterns could be integrated into derivative estimates and ratios to allow more insight and diagnostic power to fulfill information needs of business managers.

McMillan [17] suggests that before taking the plunge into social media, it is important for investment professionals and their firms to think about the content of any communications, the use of third party information, record retention, and supervisory policies. As more firms use social media platforms to communicate with clients, the line between what belongs to the firm and what belongs to the individual employee has become increasingly blurred. It is important that information professionals use policies and procedures concerning social media and related issues to encourage ethical use of information. 
Chaudhry and Al-Ansari [18] reported that investment professionals in Kuwait were frequently using electronic and digital information and social media to support their investment related work. They were using iPhone, instant messaging and email on daily basis to look for information. However, Facebook, Twitter, and blogs and wikis showed up on the bottom side. Enterprise portals and intranets, business information services, already bookmarked sites, and newspapers and industry magazines were considered the top five sources useful in seeking information related to investment activities. Bloomberg was the most frequently used electronic resource Reuter, Zawya, Economic Intelligent Unit Reports, Edger Online, and IFIS (Islamic Finance Information Service) were also among the frequently used sources.

Review of previous studies provided good clues about the aspects of information finding by professionals in the field of business and economics. These studies covered specific business information sources and information needs. This paper was intended to focus on information finding skills and difficulties experienced by business professionals in finding information. Conceptual framework shown in Figure 1 guided the study. This study will make a valuable contribution to professional literature of information finding practices in the field of business.

As shown in Figure 1, information finding involves a number of factors: knowledge workers ought to be convinced that information will help do their work better. They also need to be motivated to find information quickly. In their efforts to find relevant work related information, policies of business organization play an important role. If business enterprises are willing to allow their employees to spare time for information finding and also are willing to provide funds to subscribe to information sources they will be able to reduce the cost and save money in production and services.

\section{Methodology}

A questionnaire survey was used to collect data on information finding practices focusing on types of information, sources of information, and difficulties experienced in finding information. Questions were taken from surveys used in earlier relevant studies. Some adjustments were made and questionnaire was reviewed by colleagues in the Department of Library and Information Science who suggested some changes. Additional questions were added about demographics of respondents. An email communication was sent to major business organizations listed on the website of the Kuwait Chamber of Commerce and Industry. An introductory cover letter explained the purpose of the survey. The objective was to collect as many responses as possible.

The email invitation was sent to the selected business organizations through business development, competitive intelligence and information technology departments requesting them to forward the link for the online survey to relevant professionals. Even though the cover letter and follow up phone calls assured anonymity and use

\section{Conceptual Framework for Information Finding}

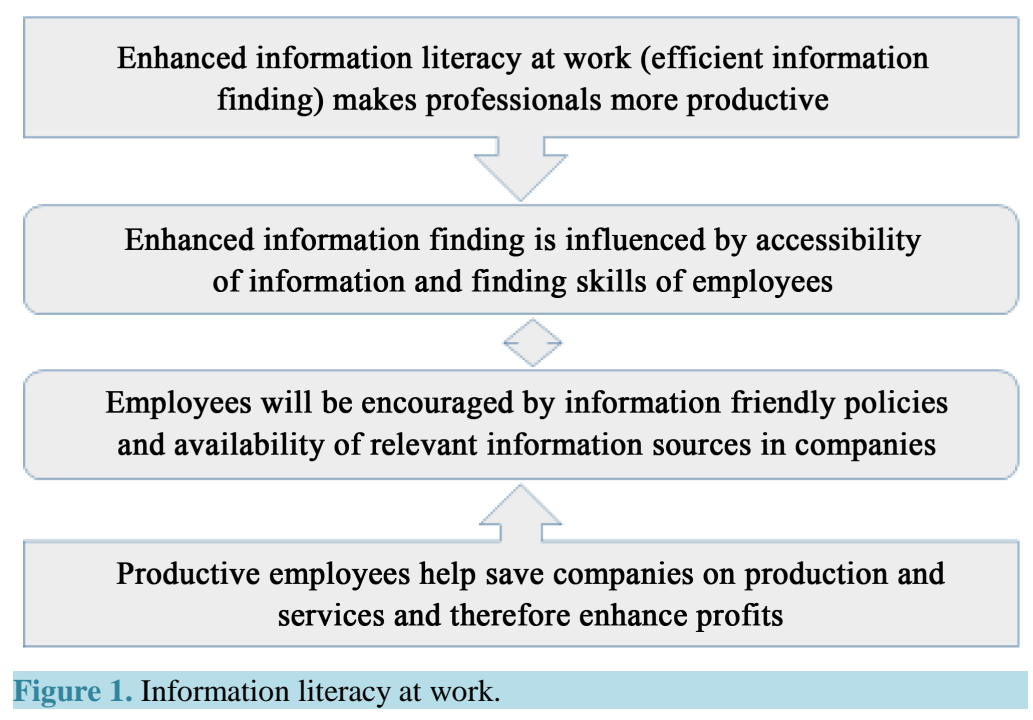


of information for research and academic purposes only, there was generally hesitation to provide information. Response to the initial invitation was not very encouraging. Repeated reminders helped in getting 35 responses.

Number of companies identified from the website of Kuwait Chamber of Commerce of Industry was 65. Responses could be obtained from 19 companies. Number and contact details of knowledge workers in these companies were not available on this site. The companies that we approached were not forthcoming in providing details about their employees. However, they did agree to forward link to our online questionnaire to relevant employees. We requested to contact those employees who had a minimum of graduate degree and were assigned professional work in the area of specialization. With multiple efforts, the number of responses reached 45 . These responses represent business organizations in different sectors including banks, investment companies, and different types of other financial institutions.

Responses were collected through Survey Monkey.com. This web questionnaire tool has good feature of providing analysis of collected data. Using this feature basic statistical analysis was performed. These statistics were used to generate tables. Demographics of responses are given in Table 1.

All respondents in the study at least have a bachelor's degree in their respective area of work. Seventy per cent were male. They appeared to be in the beginning of their professional career as about 50 per cent were in the age group from 30 - 39 and more than $30 \%$ had more than five years of work experience.

\section{Results and Discussion}

\subsection{Approaches to Information Finding}

The participants considered included the following as important types of information required to support financial analysis work: information on countries, investment opportunities, projects, business owners and their priorities. Earlier studies have indicated that information is the life blood of business organizations. Feldman and Sherman [19] stated that timely access to critical information separates the winners from the losers in today's information economy. Professionals in most business organizations too often fail in their quest to obtain the information they need. The amount of time wasted in futile searching for vital information is enormous, leading to staggering cots to the enterprise.

A question was asked about how business professionals looked for information once need for information was recognized (what did they do to find the information). A list of possible approaches was presented and they were asked to indicate the frequency of using the listed approaches. A summary of their responses ranked by frequency of responses is given in Table 2.

As expected (and reported by various previous studies. e.g., Choo et al. [20]; Chaudhry [21] [22], most of the participants (78\%) chose web sites as their preferred means for finding information. As shown in Table 1, participants also reported use of internal reports and consulting with colleagues as their preferred approaches. Financial advisors and fund managers also appeared among the preferred approaches. Personal documents, libraries \& information centers and chambers of commerce were listed as the leased preferred approaches. This appears to be a reflection of unawareness about the valuable resources that can be accessed through these means.

\begin{tabular}{|c|c|c|}
\hline Feature & Range & Percentage \\
\hline \multicolumn{3}{|l|}{ Age } \\
\hline & 20 - 29 years & 25.00 \\
\hline & 30 - 39 years & 51.67 \\
\hline & 40 - 49 years & 11.67 \\
\hline & 50 - 59 years & 10.00 \\
\hline & 60 or above & 1.67 \\
\hline \multicolumn{3}{|l|}{ Experience } \\
\hline & 1 - 5 years & 18.33 \\
\hline & $6-10$ years & 33.33 \\
\hline & 11 - 15 years & 36.67 \\
\hline & 10 or above & 11.67 \\
\hline
\end{tabular}


Table 2. Approaches used to find information $(\mathrm{N}=45)$.

\begin{tabular}{ccc}
\hline Rank & Approach & Percentage \\
\hline 1 & Search websites, portals, intranets and other organizational sites & 77.97 \\
2 & Search databases related to the business field & 59.32 \\
3 & Consult Government publications \& reports & 52.54 \\
4 & Review internal reports and studies & 49.15 \\
5 & Seek advice from colleagues & 49.15 \\
6 & Search newspapers and magazines & 49.15 \\
7 & Read reports from competitors & 47.46 \\
8 & Browse company information systems & 44.07 \\
9 & Consult fund managers and financial advisors & 40.68 \\
10 & Look through personal documents & 35.59 \\
11 & Search in library or information center & 27.12 \\
12 & Browse chamber of commerce sources & 27.12 \\
\hline
\end{tabular}

Participants reported that they would browse and read relevant trade journals before consulting other means and indicated using Big 4 knowledge database as their starting point for information finding. Consult industry practices and international was also considered useful because local information agencies prefer to escalate the actual underlying information.

\subsection{Preferred Information Sources}

A question asked the respondents to indicate their preference for information sources considering relevance, access, ease of use, accuracy and currency. These factors were selected based on the best practices of information services for reviewing the quality of information sources. They indicated the preferences on a scale of 1 to 1 5 ( 1 being the least preferred and 5 the most preferred). Their responses are shown in Table 3.

As shown in Table 3, organizational sites, reports from financial analysts and business information services were considered among the top sources of information preferred in seeking information to support business work. Since most newspapers and industry magazines are available online it is quite natural that participants considered these as important.

The participants of this study also listed social media among the most frequently used sources by business professionals. Their feedback with regard to use of social media for information finding is given in Table 4 .

As shown in Table 4, wikis and blogs were used most frequently by business professionals. They also used LinkedIn, Twitter, and Facebook very frequently. Earlier information behavior research in Kuwait also highlighted use of social media among professionals in different industry sectors. In these studies, blogs and wikis were on the bottom side, Kassim [23]; Chaudhry and Al-Mahmood [24]; and Chaudhry, Rehman, and Al-Sughair [25]. In this study it is the other way around. This shows that business professionals have different outlook towards use of social media software and better appreciation for the potential of blogs and wikis.

\subsection{Barriers to Finding Information}

Participants were asked about what difficulties they generally experience in searching/finding information. Their responses are summarized in Table 5.

As shown in Table 5, participants were concerned for subscriptions requirement and the classified nature of information in some sources ( $77 \%$ and $58 \%$ ). The participants pointed out the following difficulties: adequate information is not available in databases; lack of good sources for on the local situation and for the region; data is not updated and not adequate research is carried out. Though lack of information finding skills appeared at the bottom of the list of difficulties, in response to another questions the participants mentioned that they would like to improve their information finding though information literacy courses. Need for training on information searching and courses for information literacy at work were also identified by earlier information behavior studies, e.g., Thivant and Bouzidi Devasagyam [26] and Johns-Masten, and McCollum [27]. 
Table 3. Preference for information sources $(\mathrm{N}=45)$.

\begin{tabular}{ccc}
\hline Rank & Source & Average score \\
\hline 1 & Websites and other organizational sites & 3.78 \\
2 & Reports from financial analysts & 3.76 \\
3 & Business information services & 3.47 \\
4 & Industry magazines and trade journals & 3.29 \\
5 & Advice from business consultants & 3.22 \\
6 & Personal documents & 2.63 \\
7 & Libraries and information centers & 2.59 \\
8 & Chambers of commerce sources & 2.58 \\
9 & Blogs & 2.28 \\
10 & Social media & 2.25 \\
\hline
\end{tabular}

\begin{tabular}{ccc} 
Table 4. Use of social media $(\mathrm{N}=45)$. & \\
\hline Rank & Media & Average \\
\hline 1 & Wikis & 3.10 \\
2 & Blogs & 2.58 \\
3 & LinkedIn & 2.51 \\
4 & Twitter & 2.20 \\
5 & Facebook & 2.16 \\
6 & Whats App & 1.98 \\
\hline
\end{tabular}

\begin{tabular}{ccc} 
Table 5. Barriers to information finding $(\mathrm{N}=45)$. \\
\hline Rank & Barriers & $\begin{array}{c}\text { Percentage of } \\
\text { responses }\end{array}$ \\
\hline 1 & Requirement of subscription the access the sources & 77.19 \\
2 & Information covered is of is classified nature. & 57.89 \\
3 & Enough time not available to find information. & 36.84 \\
4 & Availability of too much information creating overload. & 6.84 \\
5 & Information finding skills are not effective. & 12.28 \\
\hline
\end{tabular}

\section{Conclusions and Recommendations}

Nature of information in the business field is complex. Employees working in companies in this sector desire to have information skills that help them find information quickly and choose appropriate information sources related to their work. Information literacy at work therefore is considered crucial among knowledge workers (professional staff) in the business and economics sectors. Knowledge workers in Kuwait considered company information as the most important among their information needs and also indicated that information on countries and investment opportunities was crucial in their work. Use of internal reports and consulting with colleagues were considered among preferred approaches for finding information. Approaching the financial consultants and fund managers when need arose for information also appeared among the preferred approaches. Unlike research reported in earlier studies, using personal documents did not appear as a preferred starting step for finding information. Libraries \& information centers and chambers of commerce \& industry were also listed as the least preferred channels. Implication of this finding is that business organizations need to create more awareness about these valuable resources. Need for subscriptions and the classified nature of information in some sources 
appeared to be the main concerns hindering information finding. Lack of adequate information in relevant databases and paucity of good sources for local and regional information were also listed as barriers towards adequacy of business information.

Most knowledge workers in the business sector in Kuwait perceived that they possessed reasonable informing finding skills but expressed that they would like to get more training in electronic database searching and familiarity with main sources of information. Arrangements by business organizations are desirable for facilitating access to information sources identified as frequently used sources either through in-house information support facilities or through partnership and alliances with outside information agencies or outsourcing arrangements with information providers. Easy access to information sources will help save valuable time of business professionals for their core duties. In addition, enhanced information literacy at work through appropriate training in database searching and information finding from specific business information sources will contribute to savings for business organizations as businesses end up losing considerable resources as a result of poor information finding capabilities of their staff.

\section{References}

[1] Ashill, N. and Jobber, D. (2001) Defining the Information Needs of Senior Marketing Executives: An Exploratory Study. Qualitative Market Research: An International Journal, 4, 52-61. http://dx.doi.org/10.1108/13522750110364578

[2] Varga-Atkins, T. and Ashcroft, L. (2004) Information Skills of Undergraduate Business Students-A Comparison of UK and International Students. Library Management, 25, 39-55.

[3] Lehmann, C. and Carolyn, S. (2005) Teaching Business Students to Recognize a Firm in Distress: What Information Is Important to Experts? Journal of Education for Business, 81, 91-98.

[4] Thivant, E. (2005) Information Seeking and Use Behaviour of Economists and Business Analysts. Information Research, 10, Paper 234. http://InformationR.net/ir/10-4/paper234.html

[5] Majid, S., Hayat, I., Patel, R. and Vijayaraghavan, S. (2012) Information Needs and Seeking Behavior of Business Students. Singapore Journal of Library and Information Management, 41, 2012. http://www.las.org.sg/sjlim/SJLIM2012MajidetalInformation.pdf

[6] Du, J. (2014) The Information Journey of Marketing Professionals: Incorporating Work Task—Driven Information Seeking, Information Judgments, Information Use, and Information Sharing. Journal of the Association for Information Science and Technology, 65, 1850-1869. http://dx.doi.org/10.1002/asi.23085

[7] Quinn, T. and Leligdon, L. (2014) Executive MBA Students' Information Skills and Knowledge: Discovering the Difference between Work and Academics. Journal of Business \& Finance Librarianship, 19, 234-255. http://dx.doi.org/10.1080/08963568.2014.916540

[8] Bennett, R. (2007) Sources and Use of Marketing Information by Marketing Managers. Journal of Documentation, 63, 702-726. http://dx.doi.org/10.1108/00220410710827763

[9] Hitch, B. (2011) Three Types of Information Needed by Marketing Managers. Marketing Management. http://www.marketing91.com

[10] Du, J., Liu, Y., Zhu, Q. and Chen, Y. (2013) Modeling Marketing Professionals' Information Behavior in the Workplace: Towards a Holistic Understanding. Information Research, 18, Paper 560. http://InformationR.net/ir/18-1/paper560.html

[11] Gunn, M. and Miree, C. (2012) Business Information Literacy Teaching at Different Academic Levels: An Exploration of Skills and Implications for Instructional Design. Journal of Information Literacy, 6, 17-34. http://dx.doi.org/10.11645/6.1.1671

[12] Hesseldenz, P. (2012) Information Literacy and the Evolving MBA Degree. Journal of Business \& Finance Librarianship, 17, 287-299. http://dx.doi.org/10.1080/08963568.2012.712496

[13] Mackenzie, M. (2005) Managers Look to the Social Networks to Seek Information. Information Research, 10, No. 2. http://InformationR.net/ir/10-2/paper216.html

[14] Kingsford-Smith, D. and Williamson, C. (2004) How Do Online Investors Seek Information, and What Does This Mean for Regulation? The Journal of Information, Law and Technology. http://www2.warwick.ac.uk/fac/soc/law/elj/jilt/2004_2/kingsford-smithandwilliamson/.

[15] Jin, T. and Bouthilier, F. (2008) Information Behavior of Competitive Intelligence Professionals: A Convergence Approach. Proceedings of the 36th Annual Conference of Canadian Association of Information Science (CAIS), University of British Columbia, Vancouver, British Columbia. 
[16] Skyrius, R. and Bujauskas, B. (2010) A Study on Complex Information Needs in Business Activities. Informing Science: the International Journal of an Emerging Transdiscipline, 10, 1-13.

http://www.inform.nu/Articles/Vol13/ISJv13p001-013Skyrius550.pdf

[17] McMillan, M. (2012) Ethics and Social Media: Four Key Considerations for Investment Professionals. Enterprising Investor.

http://blogs.cfainstitute.org/investor/2012/07/26/ethics-and-social-media-4-things-investment-professionals-and-firms-s hould-think-about-before-using-social-media/

[18] Chaudhry, A. and Al-Ansary, H. (2013) Use of Digital and Electronic Information by Investment Professionals in Kuwait. Library Review, 62, 157-176. http://dx.doi.org/10.1108/00242531311329482

[19] Feldman, S. and Sherman, C. (n.d.) The High Cost of Not Finding Information: An IDC White Paper. http://www.ejitime.com/materials/IDC\%20on\%20The\%20High\%20Cost\%20Of\%20Not\%20Finding\%20Information.p df

[20] Choo, C.W., Detlor, B. and Turnbull, D. (2000) Web Work: Information Seeking and Knowledge Work on the World Wide Web. Kluwer Academic Publishers, Dordrecht, The Netherlands. http://dx.doi.org/10.1007/978-94-015-9405-9

[21] Chaudhry, A. (2013) Information Management Strategies of Knowledge Workers in the Public Sector in Kuwait. Libri: International Journal of Libraries and Information Services, 63, 149-158. http://dx.doi.org/10.1515/libri-2013-0012

[22] Chaudhry, A. (2014) Leveraging Personal Networks for Strengthening Personal Knowledge Management. Libri: International Journal of Libraries and Information Services, 64, 341-353. http://dx.doi.org/10.1515/libri-2014-0027

[23] Kassim, N. (2010) Business Information Needs and Managing Information among Malaysian Bumiputera Would Be Entrepreneurs. Malaysian Journal of Library \& Information Science, 15, 57-69.

[24] Chaudhry, A., Rehman, S. and Al-Sughair, L. (2015) Personal Information Management Practices in the Kuwaiti Corporate sector. International Journal for e-Learning Security, 5.

[25] Chaudhry, A. and Al-Mahmood, S. (2015) Information Literacy at Work: A Study of Information Management Behavior of Kuwaiti Engineers. Electronic Library, 33, 760-772. http://dx.doi.org/10.1108/EL-04-2014-0063

[26] Devasagyam, R., Johns-Masten, K. and McCollum, J. (2012) Linking Information Literacy, Experiential Learning, and Student Characteristics: Pedagogical Possibilities in Business Education. Academy of Educational Leadership Journal, 16, 1-18.

[27] Thivant, E. and Bouzidi, L. (2008) Analysis of Information Sources Representation for Financial Product Design: New Perspectives for Information Seeking and Use Behaviour. Information Research, 13, Paper 367. http://InformationR.net/ir/13-4/paper367.html

\section{Submit or recommend next manuscript to OALib Journal and we will provide best service for you:}

- Publication frequency: Monthly

- 9 subject areas of science, technology and medicine

- Fair and rigorous peer-review system

- Fast publication process

- Article promotion in various social networking sites (LinkedIn, Facebook, Twitter, etc.)

- Maximum dissemination of your research work

Submit Your Paper Online: Click Here to Submit

Contact Us: service@oalib.com 